\title{
Analgesic Effect of Dayak Onion (Eleutherine americana (Aubl.) Merr.) on Mice (Mus musculus) by Hot Plate Test Method
}

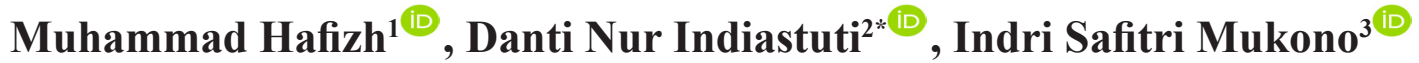 \\ ${ }^{1}$ Faculty of Medicine, Universitas Airlangga, Surabaya, Indonesia \\ ${ }^{2}$ Department of Anatomy, Histology and Pharmacology, Faculty of Medicine, Universitas Airlangga, Surabaya, Indonesia - \\ Dr. Soetomo General Academic Hospital Surabaya, Indonesia \\ ${ }^{3}$ Department of Biochemistry, Faculty of Medicine, Universitas Airlangga, Surabaya, Indonesia - Dr. Soetomo General \\ Academic Hospital Surabaya, Indonesia
}

\section{A R T I C L E I N F O}

\section{Article history:}

Received 19 May 2021

Received in revised form 17 June 2021

Accepted 24 June 2021

Available online 30 June 2021

\section{Keywords:}

Pain,

Analgesics,

Dayak onion,

Quercetin.

*) Corresponding author:

danti-n-i@fk.unair.ac.id

\begin{abstract}
A B S T R A C T
Introduction: Pain is an unpleasant experience that reduces a person's quality of life. Pain related complain can be treated by administering analgesic drugs. Several studies show that the availability of analgesics is still low, especially opioid analgesics. Dayak onion (Eleutherine americana (Aubl.) Merr.) are used by the Dayaks to relieve pain. Several empirical studies have shown that Dayak onion contain compounds including quercetin as a potential analgesic. This research aimed to investigate the potential analgesic effect of Dayak onion using hot plate method.

Methods: The research was conducted experimentally on $36 \mathrm{BALB} / \mathrm{c}$ male mice which randomly divided into 6 different treatment groups of Dayak onion exctract, aspirin, codein and aquadest. Each group were thermally pain-induced for latency period measurement by the hot plate test method. Obtained data were processed using Analysis of Variance (ANOVA) followed by Dunnett test.

Results: There was a difference in the latency period between the baseline response time and the response time after being treated in each group. ANOVA test results showed significant results $(p<0.05)$ so that the resulting latency period was significant. Dunnett test results showed significant results $(\mathrm{p}<0.05)$ in negative control group. Based on these results, Dayak onion are proven to have an analgesic effect on heat stimulation.

Conclusion: Dayak onion possess significant analgesic effect on thermally pain-induced mice. Dayak onion extract $90 \mathrm{mg} / \mathrm{kg}$ mouse produced better analgesic effects than aspirin $65 \mathrm{mg} / \mathrm{kg}$ mouse.
\end{abstract}

\section{Introduction}

Pain is an unpleasant sensory and emotional experience associated with or resembling that associated with actual or potential tissue damage. ${ }^{1}$ Pain arises from the presence of noxious stimuli such as heat which are then transferred to the brain via pain pathways. ${ }^{2}$ Pain in every individual has a relationship to their health condition so that it becomes the basis for dealing with these complaints.

Pain can be treated with analgesics. Analgesics are divided based on how they work, namely peripheral and central. Peripheral analgesics work by inhibiting the secretion of prostaglandins by the enzyme cyclooxygenase, which is stimulated by pain stimuli. While central analgesics block pain pathways in the central nervous system, causing pain impulses to be unable to pass to the brain. ${ }^{3}$

A person who experiences any kinds of pain will face various hindrances in daily life, thus it needs to be handled as soon as possible. Pain has the worst impact on a person's quality of life than any other health problem and is the biggest contributor to increasing disability worldwide. ${ }^{4}$ However, the availability of analgesics is still insufficient, especially opioid analgesics. In Indonesia, the adequacy of opioid analgesics is only $0.16 \% .^{5}$ These limitations caused 122, 142 patients in Indonesia to die with pain that could not be handled adequately 6 . These problems must be treated immediately so that pain management improves.

Dayak onion (Eleutherine americana (Aubl.) Merr.) is a plant belonging to Iridaceae family of Liliales order. This plant has bright red underground storage organs 
of bulb like onion, pseudo trunked green sword-shaped leaves and white rhipidia-shaped inflorescence. ${ }^{7}$ Dayak onion has been used by the Dayak tribe to treat menstrual pain which is triggered by an increase in prostaglandins that stimulate the pain response. ${ }^{8}$ Empirically, Dayak onion contains luteolin, which can reduce prostaglandin levels by inhibiting the action of the cyclooxygenase enzyme, thereby reducing pain. ${ }^{9,10}$ Another study shows that Dayak onion also contain quercetin which works centrally by binding to TRPV1 and opioid receptors in the spinal cord that inhibit pain impulses. ${ }^{11}$ The difference in the mechanism of action of analgesic of the two substances in Dayak onion needs to be studied further. This research was conducted to test the analgesic effect of Dayak onion on male mice using the hot plate test method.

\section{Methods}

\section{Ethical Clearance}

This in vivo study has been approved by Ethical Review Committee of Faculty of Medicine Universitas Airlangga, Surabaya, Indonesia (207/EC/KEPK/FKUA/2019).

\section{Animal Model}

A total of 36 male BALB/c mice (Mus musculus) were obtained from Mitra Kampung Jombang, East Java, in healthy condition. Mice were checked to fulfill the criteria of 6-8 weeks old with a body weight of 20-30 g. Mice were acclimatized for 7 days ad libitum to food and drink with dark/light cycles before being researched. A total of 36 mice were randomly divided into six groups for each research method.

\section{Plant Preparation}

Dayak onion were identified and obtained at UPT Laboratorium Herbal Materia Medica, Batu, East Java. Two hundred grams of Dayak onion powder was soaked with 1.5 litres of $70 \%$ alcohol for 24 hours. The bath was filtered three times. After being filtered, the filtrate was evaporated for 24 hours to produce 27 grams of extract with purple color. The preparation carried out by multiple dilutions. $^{12} 108 \mathrm{mg}$ of extract was mixed with $120 \mathrm{mg}$ of CMC Na $1 \%$ and then diluted with $12 \mathrm{ml}$ of aquadest. The result of the suspension is $90 \mathrm{mg} / \mathrm{kg}$ mouse. Then, take 8 $\mathrm{ml}$ of suspension and dilute it with $4 \mathrm{ml}$ of aquadest. The result is a dose of $60 \mathrm{mg} / \mathrm{kg}$ mouse. After that, take $6 \mathrm{ml}$ of the suspension and dilute it with $6 \mathrm{ml}$ of aquadest so that it becomes a dose of $30 \mathrm{mg} / \mathrm{kg}$ mouse.

\section{Research Design}

Mice were placed on a hot plate with a temperature of 55 \pm 0.1 degrees Celsius without being given analgesics and then the pain response was observed for the first time with the cut-off time to respond to pain within 30 seconds to avoid inflammation in the mice. Pain response time would be recorded if any of the reactions present include licking the hind leg, wagging the hind leg, or jumping. ${ }^{13}$

After baseline measurement, all mice were treated according to their group. Every dose was orally administered in single dose. Group P1, P2, and P3 were given ethanol extract of Dayak onion $30 \mathrm{mg} / \mathrm{kg}, 60 \mathrm{mg} /$ $\mathrm{kg}$, and $90 \mathrm{mg} / \mathrm{kg}$ mouse. Group $\mathrm{K} 1+$ was given a single dose of aspirin $65 \mathrm{mg} / \mathrm{kg}$ mouse. Group K2+ was given a single dose of codeine $30 \mathrm{mg} / \mathrm{kg}$ mouse. Aspirin and codein are used as positive controls due to analgesic effect of Dayak onion is affected to the concentration of luteolin and quercetin that have different analgesic mechanism of action. Luteolin acts as peripheral analgesic similar to aspirin while quercetin acts as central analgesic similar to codeine. Group K- was given aquadest $0.2 \mathrm{ml}$ as negative control.

After pain baseline was measured, mice were treated according to the provisions of each group and then left to stand for 30 minutes. The mice were again placed on the hot plate with a temperature of $55 \pm 0.1$ degrees Celsius. Pain response time would be recorded if any of the reactions present include licking the hind leg, wagging the hind leg, or jumping. The time recorded was the first pain response time. The method was then repeated at 30 minute intervals until the third pain response time was obtained.

\section{Data Analysis}

The data were collected by recording the time on the stopwatch when the mice showed first pain response. The data were processed using IBM SPSS Statistics 23. The significance of latency period of each group was analyzed using Paired Sample T-Test and the significance of latency period among groups was analyzed using Analysis of Variance (ANOVA). The significance of mean latency period between treatment groups and control groups was analyzed using Dunnett test. Processed data is considered to have a significant difference if the significance value is less than $0.05(\mathrm{p}<0.05)$.

\section{Results}

The data obtained from each treatment group were averaged from three repetitions and presented in Table 1. It is known that the response time of mice produced after being treated is longer than that of baseline. The standard deviation of each group is lower than the mean response time which means that the data variation is low.

The collected data were then analyzed for normality and homogeneity. It is known that the data collected has a normal distribution $(\mathrm{p}>0.05)$ and homogeneous $(p>0.05)$. The mean response time of mice when baseline and after the treatment was analyzed by using comparative test Paired Sample T-Test to determine the significant difference in latency period. The results of the analysis showed that there was a significant difference in the latency period $(p<0.05)$ except for the negative control group with $\mathrm{p}>0.396$.

The mean latency period was tested for comparison with one-way ANOVA to determine whether the difference in latency period between groups was significant. The results of the comparative test showed a significant value $(p<0.05)$ so that the differences in the latency period between groups were significant. The difference in latency period of treatment groups and control groups were compared with Dunnett test. The results of the analysis shows that there was a significant difference of treatment groups and negative control group $(\mathrm{p}<0.05)$ and no significant difference between treatment groups and positive control groups. 
Table 1. Mean latency period and significance of Dayak onion analgesic from averaged three repetitions of hot plate test

\begin{tabular}{clcccc}
\hline Group & \multicolumn{1}{c}{ Treatment } & Baseline (s) & After Treatment (s) & Latency Period (s) & P Value \\
\hline P1 & Dayak onion extract 30 mg/kg mouse & $16.90 \pm 3.50$ & $27.63 \pm 4.03$ & $10.73 \pm 5.20$ & 0.004 \\
\hline P2 & Dayak onion extract $60 \mathrm{mg} / \mathrm{kg}$ mouse & $16.72 \pm 4.53$ & $30.5 \pm 7.18$ & $13.78 \pm 7.14$ & 0.005 \\
\hline P3 & Dayak onion extract $90 \mathrm{mg} / \mathrm{kg}$ mouse & $17.38 \pm 4.26$ & $32.35 \pm 8.98$ & $14.97 \pm 5.96$ & 0.002 \\
\hline $\mathrm{K} 1+$ & Aspirin $65 \mathrm{mg} / \mathrm{kg}$ mouse & $17.45 \pm 5.29$ & $30.67 \pm 6.78$ & $13.80 \pm 6.65$ & 0.006 \\
\hline $\mathrm{K} 2+$ & Codeine $30 \mathrm{mg} / \mathrm{kg}$ mouse & $18.98 \pm 4.69$ & $35.83 \pm 8.68$ & $16.87 \pm 8.30$ & 0.004 \\
\hline $\mathrm{K}-$ & Aquadest $0.2 \mathrm{ml}$ & $17.10 \pm 4.58$ & $18.82 \pm 5.60$ & $1.71 \pm 4.53$ & 0.396 \\
\hline
\end{tabular}

Table 2. Mean latency period of Dayak onion analgesic comparison test

\begin{tabular}{|c|c|c|c|c|}
\hline Treatment Group & Treatment & Control Group & Control & P Value \\
\hline \multirow{3}{*}{ P1 } & \multirow{3}{*}{$\begin{array}{c}\text { Dayak onion extract } 30 \\
\mathrm{mg} / \mathrm{kg} \text { mouse }\end{array}$} & $\mathrm{K} 1+$ & Aspirin $65 \mathrm{mg} / \mathrm{kg}$ mouse & 0.735 \\
\hline & & $\mathrm{K} 2+$ & Codeine $30 \mathrm{mg} / \mathrm{kg}$ mouse & 0.295 \\
\hline & & $\mathrm{K}-$ & Aquadest $0.2 \mathrm{ml}$ & 0.036 \\
\hline \multirow{3}{*}{$\mathrm{P} 2$} & \multirow{3}{*}{$\begin{array}{c}\text { Dayak onion extract } 60 \\
\mathrm{mg} / \mathrm{kg} \text { mouse }\end{array}$} & $\mathrm{K} 1+$ & Aspirin $65 \mathrm{mg} / \mathrm{kg}$ mouse & 1.000 \\
\hline & & $\mathrm{K} 2+$ & Codeine $30 \mathrm{mg} / \mathrm{kg}$ mouse & 0.770 \\
\hline & & K- & Aquadest $0.2 \mathrm{ml}$ & 0.005 \\
\hline \multirow{3}{*}{ P3 } & \multirow{3}{*}{$\begin{array}{c}\text { Dayak onion extract } 90 \\
\mathrm{mg} / \mathrm{kg} \text { mouse }\end{array}$} & $\mathrm{K} 1+$ & Aspirin $65 \mathrm{mg} / \mathrm{kg}$ mouse & 0.977 \\
\hline & & $\mathrm{K} 2+$ & Codeine $30 \mathrm{mg} / \mathrm{kg}$ mouse & 0.929 \\
\hline & & K- & Aquadest $0.2 \mathrm{ml}$ & 0.002 \\
\hline
\end{tabular}

\section{Discussion}

The results showed that there was an analgesic effect produced by the dayak onion extract in mice with hot plate test method. Analysis results indicated that the resulting latency period were significant other than that of the negative control group and those latency period had significant differences between groups.

The analgesic effect comes from quercetin and luteolin. Quercetin is a type of flavonoid which forms the basic structure for forming other flavonoids. Quercetin is absorbed by the body in the small intestine and then transferred to the liver via the portal circulation before experiencing the first pass effect. After that, the quercetin will spread to various tissues in the body. Quercetin is known to bind strongly to albumin in plasma. ${ }^{14}$ Quercetin has an opioid effect and inhibits the Transient Receptor Potential Cation Channel Subfamily V member 1 (TRPV1) receptor. ${ }^{11,15}$ Luteolin is a flavone that functions as a plant cell defense from microorganisms and ultraviolet light. Luteolin is often glycosylated in plants, and the glycosides are hydrolyzed to release luteolin during absorption. ${ }^{14}$ Luteolin reduces prostaglandin levels by inhibiting the action of the cyclooxygenase enzyme, thereby reducing pain. ${ }^{9,10}$ Although luteolin also induces analgesic effect, hot plate test is not a sensitive test to evaluate peripheral analgesic effect because thermal pain mainly mediates central sensitization. ${ }^{16}$

Dayak onion extract $30 \mathrm{mg} / \mathrm{kg}$ mouse has been able to produce significant analgesic effects. At a dose of $60 \mathrm{mg} / \mathrm{kg}$ mouse, Dayak onion produced a better effect than $30 \mathrm{mg} /$ $\mathrm{kg}$ mouse. Dayak onion extract $90 \mathrm{mg} / \mathrm{kg}$ mouse produced better analgesic effects than the two previous extract doses and aspirin $65 \mathrm{mg} / \mathrm{kg}$ mouse but not better than codeine 30 $\mathrm{mg} / \mathrm{kg}$ mouse. Increasing the dosage indicates an increase in the effects also showed in a study where increasing dosage of Dayak onion leaves extract improved antioxidants effect which helps reducing pain. ${ }^{17}$ Further research is needed regarding the dose of Dayak onion which produces more optimal analgesic effect. The dosage of Dayak onion extract used is known to have no side effects because signs of toxicity appear when the dose reaches $5.2 \mathrm{mg} / 20 \mathrm{~g}$ or $260 \mathrm{mg} / \mathrm{kg}$ mouse. ${ }^{18}$

\section{Conclusion}

Dayak onion extract can produce significant analgesic effects in male mice tested with hot plate test. Dayak onion extract $90 \mathrm{mg} / \mathrm{kg}$ mouse produced better analgesic effects than aspirin $65 \mathrm{mg} / \mathrm{kg}$ mouse.

\section{Acknowledgement}

We are very grateful for all the doctors and staffs of Department of Medical Pharmacology and Department of Medical Biochemistry Faculty of Medicine Universitas Airlangga for their assistance during the research.

\section{Conflict of Interest}

The author stated there is no conflict of interest

\section{References}

1. Raja SN, Carr DB, Cohen M, Finnerup NB, Flor H, Gibson S, et al. The revised International Association for the Study of Pain definition of pain: concepts, challenges, and compromises. Pain. 2020;161(9):1976-1982.

2. Hall J, Hall M. Guyton and Hall Textbook of Medical Physiology. 14th ed. Philadelphia; Elsevier; 2020.

3. Katzung B, Kruidering-Hall M, Trevor A. Katzung \& Trevor's Pharmacology.11th ed. New York; McGraw-Hill Education; 2015.

4. Henschke N, Kamper SJ, Maher CG. The epidemiology and economic consequences of pain. Mayo Clinic Proceedings. 2015;90(1):139147. 
5. Duthey B, Scholten W. Adequacy of opioid analgesic consumption at country, global, and regional levels in 2010, its relationship with development level, and changes compared with 2006. Journal of Pain and Symptom Management. 2014;47(2):283-297.

6. Jemal A, Torre L, Street W, Bray F. The Cancer Atlas - ACS. $3^{\text {rd }}$ ed. Atlanta; American Cancer Society; 2019:1-69

7. Daryono BS, Rahmadani WD. Identification of Bawang Sabrang (Eleutherine americana Merr . Ex K . Heyne ) in Indonesia Based on Chromosome Characters. Indonesia Journal of Pharmacy. 2013;24(1):22-9.

8. Luardini MA, Asi N, Garner M. Ecolinguistics of ethno-medicinal plants of the Dayak Ngaju community. Language Science. 2019;74:77-84

9. Park CM, Song YS. Luteolin and luteolin-7-o-glucoside inhibit lipopolysaccharide-induced inflammatory responses through modulation of NF $-\kappa B / A p-1 / P I 3 K-A K T$ signaling cascades in RAW 264.7 cells. Nutrition research and practice. 2013;7(6):423-429.

10. Naspiah N, Iskandar Y, Moelyono MW. Review Article: Tiwai Onion (Eleutherine americana Merr.), multifunction plant. Indonesian Journal of Applied Sciences. 2014;4(2):18-30.

11. Borghi SM, Pinho-Ribeiro FA, Fattori V, Bussmann AJC, Vignoli JA, Camilios-Neto D, et al. Quercetin inhibits peripheral and spinal cord nociceptive mechanisms to reduce intense acute swimming-induced muscle pain in mice. PLoS ONE. 2016;11(9):1-23.

12. Suprapti T. Praktikum Farmasetika Dasar. Kementerian Kesehatan Republik Indonesia. 2016;1(2):61-68.
13. Mulder G., Pritchett-Corning K. Rodent analgesiometry: The hot plate, tail flick dan Von Frey hairs. Contemporary topics in laboratory animal science/American Association for Laboratory Animal Science. 2004; 43(3):54-55

14. Ruiz-Miyazawa KW, Staurengo-Ferrari L, Mizokami SS, Domiciano TP, Vicentini FTMC, Camilios-Neto D, et al. Quercetin inhibits gout arthritis in mice: induction of an opioid-dependent regulation of inflammasome. Inflammopharmacology. 2017;25(5):555-570.

15. Backhouse N, Delporte C, Apablaza C, Farías M, Goïty L, Arrau S, et al. Antinociceptive activity of Buddleja globosa (matico) in several models of pain. J Ethnopharmacol. 2008;119(1):160-165.

16. Ribeiro N, Abreu T, Chaves H, Bezerra M, Monteiro H, Jorge R et al. Sulfated polysaccharides isolated from the green seaweed Caulerpa racemosa plays antinociceptive and anti-inflammatory activities in a way dependent on $\mathrm{HO}-1$ pathway activation. Inflammation Research. 2014;63(7):569-580.

17. Idrus HRA, Iswahyudi, Wahdaningsih S. Uji Aktivitas Antioksidan Ekstrak Etanol Daun Bawang Mekah (Eleutherine americana Merr.) Terhadap Gambaran Histopatologi Paru Tikus (Rattus norvegicus) Wistar Jantan Pasca Paparan Asap Rokok. Jurnal Fitofarmaka Indonesia. 2014;1(2):51-60.

18. Sastyarina Y. Uji toksisitas akut dan subakut pada pemberian ekstrak etanol bawang tiwai (Eleutherine americana Merr.). Journal of Tropical Pharmacy and Chemistry. 2013;2(2):18-124. 